\title{
MODELOS DE CIENTIFICIDADE DA GRAMÁTICA EM DISPUTA NO BRASIL NO FIM DO SÉCULO XIX: A POLÊMICA ENTRE JÚLIO RIBEIRO E AUGUSTO FREIRE DA SILVA
}

\author{
SCIENTIFIC MODELS OF GRAMMAR IN DISPUTE \\ IN BRAZIL ATTHE END OFTHE NINETEENTH \\ CENTURY: THE CONTROVERSY BETWEEN JÚLIO \\ RIBEIRO AND AUGUSTO FREIRE DA SILVA
}

\author{
José Edicarlos de Aquino \\ Universidade Federal do Tocantins \\ edicarlos_aquino@yahoo.com.br
}

Resumo:

Este artigo trata dos modelos de cientificidade da gramática em disputa no Brasil no fim do século XIX, analisando a polêmica os gramáticos Júlio Ribeiro e Augusto Freire da Silva, que tem como fundamento justamente uma discordância quanto às bases científicas do estudo da linguagem e à definição, divisão e orientação teórica da gramática. Chamando a atenção para a existência de todo um movimento gramatical importante no Brasil a ser considerado além do eixo Rio de Janeiro-São Paulo, mostramos como a gramática geral e a gramática histórica-comparada concorrem como padrão de ciência na produção gramatical brasileira na virada para o século XX, sendo não apenas retomadas, tal como trabalhadas no exterior, mas ressignificadas, num movimento de reivindicação de um trabalho autoral pelos gramáticos brasileiros.

PALAVRAS-CHAVE: Polêmica Gramatical, Júlio Ribeiro, Augusto Freire da Silva, Gramática Geral, Gramática Histórico-Comparada.

ABSTRACT: This article deals with the scientific models of grammar in dispute in Brazil at the end of the nineteenth century, analyzing the controversy between the grammarians Júlio Ribeiro and Augusto Freire da Silva, which is based precisely on a disagreement about the scientific basis of the study of language and the definition, division and theoretical orientation of grammar. Drawing attention to the existence of an important grammatical movement in Brazil to be considered beyond the Rio de Janeiro-São Paulo axis, we show how general grammar and historical-comparative grammar compete as a standard of science in Brazilian grammar production in the turn 
towards the twentieth century, being not only copied, as worked abroad, but resignified, in a movement of claiming an authorial work by Brazilian grammarians.

KEYWORDS: Grammatical controversy, Júlio Ribeiro, Augusto Freire da Silva, General grammar, Historical-comparative grammar.

\section{Introdução}

Entre 17 de dezembro de 1879 e 16 de janeiro de 1880, Júlio Ribeiro travou uma discussão nos jornais com o gramático maranhense Augusto Freire da Silva, o primeiro escrevendo no Diario de Campinas e o outro na Provincia de São Paulo ${ }^{1}$.

As polêmicas são comuns no Brasil do fim do século XIX como meio de debate linguístico, colocando questões sobre o modo como os brasileiros falam e escrevem e, nessa atividade, construindo discursos metalinguísticos sobre a língua nacional no período da gramatização do português do Brasil, como explica Pfeiffer (2001). Essa época vai assistir às contendas entre o escritor brasileiro José de Alencar e o filólogo português Pinheiro Chagas, entre o escritor português Camilo Castelo Branco e o jornalista e político brasileiro Carlos de Laet, entre Carlos de Laet novamente e o filólogo português Pinheiro Chagas, além da disputa entre os brasileiros Carneiro Ribeiro, professor e filólogo, e Rui Barbosa, senador. Inserir Júlio Ribeiro e Augusto Freire da Silva como uma página na história das polêmicas linguísticas no Brasil, sendo ela raramente lembrada, para não dizer rasgada, constitui uma contribuição pretendida por nosso estudo. É verdade que não somos os primeiros a apontar essa polêmica; contudo, para além de relatar simplesmente as questões gramaticais aí tratadas, como fazem os poucos trabalhos ${ }^{2}$ que sobre ela já se detiveram, a contribuição que pretendemos trazer consiste em mostrar que essa polêmica é menos sobre o modo como os brasileiros falam e escrevem, embora essas questões também apareçam, do que sobre a maneira como se deve falar sobre a linguagem e produzir os instrumentos linguísticos. Dito de outro modo, essa polêmica é menos sobre as línguas do que sobre as ideias sobre elas, isto é, sobre a descri-

Esses artigos foram reunidos no livro Questão Grammatical, publicado em 1887. É a redação dessa obra que utilizamos no presente artigo.

2 Na verdade, encontramos apenas um único trabalho sobre essa polêmica. Trata-se de um artigo de Maurício Silva (2010), cuja referência pode ser encontrada no final deste artigo. 
ção e a explicação linguística, enfim, sobre o saber metalinguístico. De fato, à diferença de outras querelas, as bases científicas do estudo da linguagem e os fundamentos teóricos da gramática não aparecem como derivação de outras questões, mas constituem antes o ponto de partida e o próprio fundamento da disputa entre Júlio Ribeiro e Augusto Freire da Silva.

Nessa polêmica, identificamos um ponto levantado pelas pesquisas do projeto História das Ideias Linguísticas no Brasil que é o argumento do novo para legitimizar um modo de dizer sobre a língua que se pretende científico. Assim, a partir da leitura dos textos da polêmica, propomos analisar de que forma tal questão aparece formulada e ressignificada, produzindo deslocamentos importantes no conjunto das ideias linguísticas estabelecidas na época. Dessa forma, um elemento central que gostaríamos de apontar é que esse argumento do novo e da cientificidade nem sempre é sinônimo de gramática histórica e comparada, pois, para Augusto Freire da Silva, esses elementos são próprios da gramática geral. Ao mesmo tempo, Júlio Ribeiro é um autor que ressignifica a própria gramática histórica e comparada no momento em que trabalha com ela. Com isso tudo, procuramos mostrar que, além do lugar central do eixo Rio Janeiro e São Paulo já trabalhado por Orlandi $(2000,2002)$, que explica que maior parte das gramáticas publicadas no fim do século XIX foi escrita por professores de colégios dessas duas regiões, existiriam outros movimentos gramaticais importantes no Brasil. Essa é uma outra contribuição pretendida por nosso trabalho. De fato, a participação de Augusto Freire da Silva, um autor do Maranhão, na polêmica com Júlio Ribeiro, um mineiro que fez sua vida em São Paulo, justifica nossa posição de que a introdução da produção de gramáticas no Rio de Janeiro e São Paulo não significou a ausência ou o fim da gramática em outras partes do Brasil.

\section{As bases científicas do estudo da linguagem}

Júlio Ribeiro inicia sua série de artigos no Diario de Campinas tratando da "natureza da linguagem articulada", colocando o estudo da linguagem pelo viés da caracterização fisiológica do homem a partir de trabalhos de antropo- 
logia, especificamente o livro Anthopologie de Paul Topinard ${ }^{3}$ e, através dele, os trabalhos de M. Gaussin e M. Condereau, nomes com passagem pela Société d'anthropologie de Paris, numa rede que traz também os nomes de Abel Hovelacque e Paul Broca.

O problema levantado por Júlio Ribeiro é o da propriedade da linguagem articulada como elemento de distinção entre o homem e o animal, bem como enquanto elemento relacionado à inteligência e índice do grau de desenvolvimento e funcionamento do cérebro, inclusive como meio possibilitador da evolução progressiva do homem.

Ao debater essas questões, Júlio Ribeiro evoca e se coloca ao lado de um grande número de autores que, nas suas palavras, teriam estabelecido "bases scientificas [d] o estudo da linguagem, quer sob o ponto de vista physiologico, quer sob o ponto de vista histórico e comparativo" (1887, p. 11). São eles W. Jones, Bopp, Schleicher, Grimm, Kuhn, Chavée, Spiegel, J. Müller, Whitney, Breál e Hovelacque. Assim, ao determinar que "estudo da linguagem articulada é hoje uma parte essencial da anthropologia, e a gramática é uma sciencia" (1887, p. 12), Júlio Ribeiro aponta quem são aqueles que avançaram e aqueles que ficaram para trás nos estudos da linguagem:

Longe vamos, felizmente, do dogmatismo feroz do padre Manuel Alvares, das utopias abstrusas de Leibnitz, da metaphysica subtil de Condillac.

Longe vamos, escrevi eu.

Longe vão os Alemães, os Inglezes, os Francezes, e até... os Russos.

Nós continuamos como estavamos, socegadamente, rotineiramente.

Ainda dividimos com toda a irracionalidade (a expressão é do sr. Theophilo Braga)

3 O livro de Topinard, publicado em 1876, é organizado em três grandes eixos temáticos: De l'homme considéré dans son ensemble et dans ses rapports avec les animaux; Des races humaines; Origine de l'homme. O primeiro eixo reúne capítulos que tratam, na terminologia do autor, de características físicas, fisiológicas e patológicas dos homens em relação aos outros animais. O quinto capítulo, a partir do qual Júlio Ribeiro trabalha, como indica o seu título, Caracteres Physiologiques, vai tratar justamente das características fisiológicas dos homens, apresentando os seguintes tópicos: Développement du corps, Embryogénie, Sutures et épiphyses, Dents, Détermination de l'âge et du sexe sur le squelette, Fonctions générales et particulières, Manifestations psychiques, Faculté générale d'expression. 
a grammatica em quatro partes -Etymologia, Syntaxe, Prosodia e Orthographia, vamos adubando com muita subtileza soporifica um mixtiforio de orações absolutas, principaes, approximadas, incidentes, integrantes, restrictivas, explicativas; architectamos pyramides de complementos esdruxulos, ouriçados de distinç̧ões cerebrinas, e afinal de contas obtemos o resultado brilhante de não escrever duas linhas sem erros, e de fazer com que os rapazes fujam das classes de gramática como o diabo da cruz. $(1887$, p. 12$)$

De um lado, Manuel Alves, Leibniz e Condillac. Do outro lado, superando o dogmatismo, a utopia e a metafísica que marcariam os primeiros, estão os ingleses, os alemães, franceses e mesmo os russos, como se esses últimos não fossem esperados nessa posição. Como se percebe pelo trecho acima, o "nós" empregado por Júlio Ribeiro joga os estudos brasileiros do lado do atraso representado pelo dogmatismo, a utopia e a metafísica de Manuel Alves, Leibniz e Condillac, atraso esse que, no caso brasileiro, seria manifesto na forma da divisão da gramática e na profusão, confusão e arranjo de termos, sintáticos, no que se percebe uma questão de terminologia, mas igualmente, e talvez mais forte, de estrutura mesmo da língua, o que traria efeitos pedagógicos negativos, com o desestímulo do estudo da gramática nos jovens. Na verdade, Júlio Ribeiro não fala apenas dos estudos brasileiros, mas do conjunto dos estudos gramaticais do português feitos por brasileiros e portugueses. Nesse conjunto, figuram como exceção os "trabalhos monumentaes" de Adolfo Coelho, Teófilo Braga e Pacheco Junior, "desgraçadamente pouco vulgarisados", sendo a regra a "repetição do que disse Sotero dos Reis, que repetiu o que disse Soares Barbosa, que repetiu o que disse Lobato, que repetiu o que disse Amaro de Roboredo, que repetiu o que disseram os Affonsinhos" (1887, p. 13), numa linhagem que - a ironia é forte - passaria por Noé, Matusalém e Enoque e chegaria a Adão. Em posição contrária a de Adolfo Coelho, Teófilo Braga e Pacheco Junior como inovadores no estudo da gramática do português, os nomes de Sotero dos Reis, Soares Barbosa, Lobato e Amaro de Roboredo, frequentemente criticados na obra de Júlio Ribeiro - sobretudo os dois primeiros -, são alvos de deboche por seus estudos que se assemelhariam a fantasias, a mitos, marcados pela repetição, pela não inovação, enfim, pelo atraso.

Essas concepções de Júlio Ribeiro sobre o que seria o estudo científico da linguagem e, sobretudo, a crítica ao trabalho gramatical de Sotero dos Reis farão reagir o gramático Augusto Freire da Silva. Concebendo diferentemente o que seria um estudo científico da linguagem, os dois gramáticos tratarão 
também diferentemente a definição, a divisão e as bases científicas do estudo da gramática.

\section{A definição de gramática}

A disputa entre Júlio Ribeiro e Augusto Freire da Silva tem como ponto de partida as críticas do primeiro às definições do gramático brasileiro Sotero dos Reis de gramática geral e gramática particular. Júlio Ribeiro considera defeituosas, sob o ponto de vista prático, e falsas, sob o ponto de científico, as definições Sotero dos Reis de gramática geral como "a sciencia dos principios immutaveis e geraes da palavra pronunciada ou escripta em todas as línguas" e de gramática particular como "a arte de aplicar aos principios mutaveis e geraes da palavra as instituições arbitrarias e usuais de qualquer lingua" (1887, p. 15). Seriam defeituosas do ponto de vista prático "porque não levam luz á intelligencia do alumno, que não sabe quaes sejam esses princípios immutaveis e geraes da palavra a que elle tem de applicar as instituições usuaes e arbitrarias (!) da sua língua" (1887, p. 15-16), no que se nota não apenas a questão do ensino, mas também e principalmente a da validade de princípios universais em uma palavra.

Em seguida, são apresentadas as razões de considerar tais definições falsas sob o ponto de vista científico. Para Júlio Ribeiro, em primeiro lugar, a mudança das línguas comprova que os princípios pelos quais se regem a linguagem humana são mutáveis e "mudam com o desenvolvimento de cerebro sob a acção dos meios em que vivem as raças, sob a acção das necessidades, dos recursos, dos habitos", para logo em seguida notar que um "adulto não fala como uma criança, e nem um cidadão de hoje como um burguez da idade media" (1887, p. 16).

Como segundo ponto, Júlio Ribeiro critica a redundância que representaria falar em princípio geral, termo que, segundo o autor, é um "pleonasmo grosseiro", chegando a perguntar se haveria princípios particulares. O que se vê nesse apontamento de ordem terminológica, logo epistemológica, é justamente a natureza do princípio em jogo.

Em um terceiro tópico, Júlio Ribeiro argumenta a favor da não arbitrariedade das instituições. As instituições linguísticas - o termo é dado por ele - são designadas como "consequencias demonstradas, logicas, fataes da evolução cerebral", evolução essa que, numa associação entre o que é da ordem do natural e o que é da ordem do social, seria "influenciada pelo clima, 
pela alimentação, pelo viver social, pelo meio enfim" (1887, p. 16), razão pela qual elas não poderiam ser arbitrárias. Uma prova chamada pelo autor para a não arbitrariedade das instituições linguísticas é a lei de Grimm, "formulada claramente, mathematicamente". Em lados que se mostram opostos, temos o que é matemático e aquilo que é arbitrário. A lei é formulada matematicamente, ela não é arbitrária. No entanto, Júlio Ribeiro emprega o termo instituições e o toma como aquilo que é provado por uma lei formulada matematicamente.

O quarto e último ponto levantado por Júlio Ribeiro trata da possibilidade de aplicar princípios a instituições arbitrárias e usuais e da impossibilidade de aplicar instituições arbitrárias a princípios, o que seria possível "só si fosse possivel aplicar um facto a uma lei, ou uma nuca a um caustico!" (1887, p. 17). Nesse movimento de colocar em debate a natureza, o caráter, a definição de princípios e instituições, fatos e leis, Júlio Ribeiro acusa uma utilização indevida do "grande nome do grande" Du Marsais nas definições de gramática geral e gramática particular "que se nos antolham ao abrirmos os compendios de grammatica mais em voga entre nós" (1887, p. 15).

Júlio Ribeiro considera a gramática como "o conjuncto das leis e principios porque se governa a Linguagem", razão pela qual ele a define a partir de Holmes como a "Sciencia da Linguagem" (1887, p. 18). Vemos portanto nessa definição de gramática ligada a Holmes a ideia de que a linguagem se governa por leis e princípios.

Augusto Freire da Silva entra em campo defendendo que não é o nome de Du Marsais que garante a correção das definições de gramática geral e de gramática particular apresentadas por Sotero dos Reis, tal como acusa Júlio Ribeiro, mas antes "a verdade que encerram, e que as fez serem abraçadas por Beauzée, Douchet, Girault-Duvivier, Bescherelle, Leger Noél, Sotero e outros" (1887, p. 58). Ora, se, como criticado por Júlio Ribeiro, as definições de gramática geral e de gramática particular de Sotero dos Reis se escoram no nome de Du Marsais, tal gesto, segundo sugere Augusto Freire da Silva, não pode ser interpretado como um simples argumento de autoridade, pois a ligação entre Sotero dos Reis e Du Marsais se explica pelo fato de que ambos, ao lado de Beauzée, Douchet, Girault-Duvivier, Bescherelle, Leger Noél, enxergaram e abraçaram certas verdades sobre a linguagem que os forçaram a definir gramática geral e gramática particular da única maneira possível. Em suma, a definição da gramática está ligada, é devedora e a ilustração de certas verdades.

As verdades que fundamentariam a definição de gramática dizem respeito à composição do pensamento. O que parece estar em jogo aqui é a defesa de uma tradição filosófica frente aos avanços da gramática histórica. Augusto Freire 
da Silva explica, primeiro, que todo homem pensa; depois, que o entendimento procede sempre às mesmas operações na elaboração do pensamento; e, por fim, que tais operações são enunciadas observando-se sempre os mesmos princípios. É nesse quadro que Augusto Freire da Silva insere o tratamento do juízo, argumentando que a enunciação do juízo não é devedora de "pátria, língua ou raça”, mas um algo universal, portanto, feita sempre da mesma maneira:

Quer, por exemplo, um homem, seja qual fôr a sua patria, lingua ou raça, enunciar um juizo, ha de necessariamente fazê-lo, como o têem todos feito, desde que ha humanidade, por meio de tres termos: pelo subjeito, representado pelo substantivo ou algum dos seus equivalentes, que designa a pessoa ou cousa a que se attribue alguma qualidade; pelo attributo, representado pelo adjectivo qualificativo, ou cousa que o valha, que exprime a qualidade que se attribue ao subjeito; e pelo verbo, que affirma que a qualidade existe no sujeito, ou lhe convém. $(1887$, p. 58)

Por estar fora do tempo, do espaço e das condições de vida, a enunciação de um juízo é apresentada como uma operação constante, realizada com o emprego de termos igualmente constantes, imutáveis. Augusto Freire da Silva fala inclusive em "factos de eterna verdade" ao explicar a "propriedade que tem o substantivo de designar a pessoa ou cousa, a que tem o adjectivo qualificativo de exprimir a qualidade, e a que tem o verbo de affirmar a existencia da qualidade na substancia ou no sujeito" (1887, p. 58-59). Indo mais longe na sua formulação, Augusto Freire da Silva sustenta que as palavras apresentam propriedades e princípios imutáveis e gerais em todas as línguas:

Conseguintemente são taes propriedades principios immutaveis e geraes da palavra pronunciada ou escripta em todas as linguas; constituindo o conjuncto de todos estes principios a sciencia grammatical ou a grammatica geral, perfeita é a definição, que della dá Du Marsais, já sob o ponto de vista pratico, porque, assim explicada, fica o alumno sabendo quaes sejam os principios immutaveis e geraes da palavra, já sob o ponto de vista scientifico, porque baseia-se em doutrina philosophica. (1887, p. 59)

Passando do pensamento para o juízo e desse para a palavra, saltando da palavra para a escrita, Augusto Freire da Silva dita propriedades e princípios universais do pensamento e da linguagem. É nesse esquema que Augusto Freire da Silva instrui que a gramática geral, chamada por ele de ciência gramatical, é constituída pelas propriedades e pelos princípios imutáveis e gerais da palavra 
pronunciada e escrita em todas as línguas. Existe, portanto, uma ciência gramatical que, na observação do modo de elaboração e enunciação do pensamento, se define de uma certa maneira, um modo de fazer gramática que é científico na medida em que observa e compreende o próprio modo de elaboração e enunciação do pensamento. No que se nota a questão da generalidade da ciência, é justamente por estar em consonância com a ideia da existência de propriedades e princípios imutáveis e gerais da palavra pronunciada ou escrita em todas as línguas que a definição de gramática de Du Marsais é tomada como perfeita por Augusto Freire da Silva.

É notável a descrição da gramática como uma ciência e, enquanto uma ciência, significada em articulação com a perfeição, perfeição de definição, de explicação e de doutrina. Como vemos pelo trecho acima, uma doutrina filosófica é posta como credora da gramática, ou mais precisamente, da definição de gramática. Assim, a posição, científica e perfeita, de que as palavras têm propriedades e princípios imutáveis e gerais em todas as línguas do mundo se baseia em doutrina filosófica. Na definição de gramática, no debate sobre as ideias gramaticais, a gramática entra na mesma rede em que se articulam ciência, perfeição e doutrina filosófica.

A questão posta por Augusto Freire da Silva é a de saber se o desenvolvimento do cérebro exerceria alguma influência na imutabilidade dos princípios que ele vem descrevendo, se o "adulto como a criança, um cidadão de hoje como um burguez da idade média deixariam por ventura de observar taes principios, toda a vez que tivessem de anunciar o seu pensamento" (1887, p. 59). Pelo que vimos até agora, a resposta deve ser negativa. Para responder a questão que coloca, Augusto Freire da Silva explica que as línguas divergem sensivelmente uma das outras, "conforme sua indole" (1887, p. 60).

É interessante notar que Augusto Freire da Silva vai falar também de princípio para abordar aquilo que estaria ligado ao gênio da língua, ao que caracterizaria particularmente cada língua. Nas palavras exatas de Augusto Freire da Silva, divergências do tipo entre português e o latim "constituem outras especies de principios, designados na definição de grammatica particular, pelas expressões instituições arbitrarias e usuaes de qualquer lingua, por serem de uma verdade hypothetica, ou dependente do arbitrio dos povos que os adoptaram, ou puseram em uso" (1887, p. 60-61). Assim, cada língua teria seu gênio segundo certos princípios. Haveria, portanto, duas instâncias de princípios, aqueles que valem para todas as línguas e aqueles que valem para uma língua em particular, aquilo que caracterizaria todas as línguas e aquilo que caracterizaria uma língua como diferente das outras, aquilo que marca todas 
as línguas, a linguagem, e aquilo que distingue uma língua no lote comum das línguas. É a gramática particular que se ocupa das outras espécies de princípios que não os princípios universais e imutáveis. A gramática particular trabalha no domínio das diferenças, da alteridade, domínio esse caracterizado por tudo aquilo que seria arbitrário e usual. Se cada língua contém expressões arbitrárias e usuais, a diferença entre as línguas está justamente naquilo que é arbitrário e usual. A faceta arbitrária das línguas é, na verdade, um aspecto ligado aos povos. Em suma, os princípios dependentes do arbítrio dos povos marcam a diferença de uma língua para outra e correspondem à gramática particular. É importante notar que os povos são mostrados como aquilo que faz as línguas serem particulares, que faz as diferentes línguas. E para falar de gramática particular, línguas particulares e povos, Augusto Freire da Silva emprega a expressão verdade hipotética, talvez uma forma de marcar aquilo que não é universal e imutável, aquilo que é variável. Para os princípios das particularidades das línguas, a natureza da verdade é hipotética. A "eterna verdade", para lembrar a expressão antes usada por Augusto Freire da Silva, é guardada para os princípios universais e imutáveis.

Augusto Freire da Silva aponta não apenas diferenças entre línguas, mas também diferenças em uma mesma língua no tempo, afirmando que divergências "outras se dão na mesma lingua de seculo para seculo, porque apraz ao uso modificar ou abonar praticas já estabelecidas" (1887, p. 61). Para exemplificar sua ideia, recorre às mudanças na história do português, concluindo que o "estudo de cada lingua consiste no conhecimento destes principios ou instituições arbitrarias e usuaes, applicadas ou acomodadas aos principios immutaveis e gerais da palavra" (1887, p. 61). A gramática particular aparece finalmente como a "arte" que ensina tais princípios ou instituições arbitrárias e usuais aplicados ou acomodados aos princípios imutáveis e gerais da palavra, definição que, conforme reitera Augusto Freire da Silva, foi realizada com maestria por Du Marsais. Por tudo isso que expõe, Augusto Freire da Silva considera que "devem desapparecer os escrupulos do sr. Julio Ribeiro em acceitar as expressões principio geral e principio particular" (1887, p. 61-62).

\section{Divisão da gramática}

Júlio Ribeiro recorre ao nome de Teófilo Braga (Grammatica Portugueza) para qualificar de irracional e velha a divisão da gramática em quatro, isto é, prosódia, etimologia, sintaxe e ortografia. A discussão se encaminha inicialmen- 
te para a questão de saber se a ortografia é uma parte distinta da gramática ou antes uma subdivisão da fonologia com o fim específico de estabelecer leis para a representação gráfica dos sons. Assim, Júlio Ribeiro pergunta se "na conta da pobre etymologia, que só tem por dever tractar da derivação historica, faremos correr a tarefa de classificar ideologicamente as palavras, e a de flexional-as segundo a sua natureza" (1887, p. 17-18). Vale observar a expressão "classificar ideologicamente as palavras".

Júlio Ribeiro explica o duplo aspecto sob o qual se apresentam à mente as palavras que compõem uma sentença: 1) entidades linguísticas individuais (consideradas em si, separadas); 2) entidades linguísticas coletivas (consideradas em sua coordenação, agrupadas). É por essa distinção que, segundo o autor, se dá a "divisão natural, lógica, necessaria da grammatica em duas partes" (1887, p. 19), lexeologia e sintaxe, divisão essa ligada por Júlio Ribeiro a Burgraff (Principes de Grammaire Générale), Allen e Cornwell (English Grammar), Ayer (Grammaire Comparée de la Langue Française) e Bastin (Étude Philologique de la Langue Française).

Júlio Ribeiro destaca que as palavras isoladas podem ser consideradas sob o ponto de vista fônico e sob o ponto de vista morfológico, o que deriva a subdivisão da lexeologia em fonologia e morfologia. Há ainda a observação de que a fonologia considera os sons em três aspectos, a saber, isolados, agrupados e representados graficamente, o que leva à subdivisão da fonologia em fonética, prosódia e ortografia. No que diz respeito ao ponto de vista morfológico, explica-se que a morfologia toma a palavra em três aspectos, a saber, 1) "como formando grupos correspondentes aos grupos de ideias que constituem o pensamento", 2) "como revestindo-se de formas flexionais" e 3) "como originando-se umas de outras", no que dá a subdivisão da morfologia em taxeonomia, kampenomia e etimologia $(1887$, p. 20). Por fim, a sintaxe é apresentada como o tratamento "da coordenação das palavras entre si para formar sentenças, e da coordenação de sentenças entre si para formar sentido completo" (1887, p. 21), o que justificaria assim a divisão em sintaxe léxica e sintaxe lógica. A passagem se encerra com uma observação sobre uma preferência terminológica de Júlio Ribeiro, o termo sentença, ao invés do termo período. Tal preferência, marca o próprio autor, se daria por seu seguimento dos "mestres inglezes".

Augusto Freire da Silva, ao responder Júlio Ribeiro, toma a divisão da gramática a partir do estudo da palavra, colocando esse estudo como o próprio objeto da gramática e como algo feito de duas formas, "mechanica ou logicamente, considerando-se as palavras, ou como meros vocabulos, ou 
como rigorosas palavras" (1887, p. 43). No caso do estudo das palavras mecanicamente, faz-se atenção tão somente à forma ou ao material do vocábulo, ao passo que, no caso do estudo das palavras logicamente, a atenção é dada à ideia que a palavra exprime. Em seguida, Augusto Freire da Silva estabelece os dois pontos de vista pelos quais se deve considerar a forma do vocábulo, quais sejam, o vocábulo em seus elementos fonéticos e o vocábulo em seus elementos gráficos. É por esse caminho que Augusto Freire da Silva vai reservar à prosódia o estudo dos "elementos phoneticos ou dos sons elementares e fundamentaes, isto é, de tudo quanto entende com a correcta pronuncia delles, e pontanto, dos vacabulos", destinando, por outro lado, à ortografia o estudo dos "elementos graphicos ou das lettras, isto é, de tudo quanto entende com a correcta escriptura dos vocabulos" (1887, p. 43-44). Cabe observar como a noção de correção atua explicitamente na definição dessas duas partes da gramática, a prosódia e a ortografia, colocando, consequentemente, a correção como uma tarefa da gramática.

Num comentário sobre as mudanças de posição que se operam na história da gramática quanto ao emprego e à significação dos termos, Augusto Freire da Silva afirma que "o termo prosodia, rigorosamente considerado, tem uma accepção restricta, qual a de significar o estudo da quantidade e do accento ou tom da voz", emendando que "ha muito, porém, que os grammaticos o acceitam com a significação lata da palavra orthoépia, ou como a parte da grammatica, que ensina a correcta pronuncia dos vocabulos" (1887, p. 44). Toda essa explicação visa atingir a posição de Júlio Ribeiro de considerar a prosódia como significando apenas o tratado do acento tônico. Assim, Augusto Freite da Silva questiona o proveito de substituir o termo prosódia por fonologia, "que tem significação restricta, como se vê de phoné, primeiro elemento componente desta palavra, o qual quer dizer som ou voz" (1887, p. 44). A crítica de Augusto Freire da Silva é que, por essa lógica, Júlio Ribeiro deveria "querer tambem que phonologia significasse só tractado dos sons", acepção que seria empregada "tanto pelo sr. Adolpho Coelho como pelo sr. Theofilo Braga" (1887, p. 44). A ideia não é outra senão esta: ou estão corretos os gramáticos portugueses ou está correto Júlio Ribeiro, sendo impossível todos estarem corretos ao mesmo tempo sobre esse tema, dada a lógica de definição dos termos com a qual trabalharia Júlio Ribeiro. Em todo caso, a questão que nos parece estar subjacente a essa discussão é justamente a da motivação da definição dos termos gramaticais.

A questão para Augusto Freire da Silva é o da validade da extensão de significação dos termos gramaticais. Para ele, com "o mesmo direito com que extende a significação da palavra phonologia, fazendo comprehender-se 
nella até a orthographia, estenderam os grammaticos a significação do termo prosodia, com acceitação de pronfudos pensadores deste e de outros seculos" (1887, p. 44-45).

Augusto Freire da Silva defende ser um erro compreender o termo ortografia no termo fonologia, um erro que significa "querer que phonê (som ou voz), signifique o mesmo que graphê (escripta), é baralhar idéas inteiramente distinctas, é não ser methodico, é ser arbitrario" (1887, p. 45). Augusto Freire da Silva diz que som, também chamado voz, e escrita são elementos completamente diferentes. No entanto, mais importante do que isso, ele parece dizer que nem toda extensão de significado dos termos gramaticais é válida. Para Augusto Freire da Silva, não se pode esquecer, é preciso levar em consideração a aceitação dos pares e autoridade dos "profundos pensadores" do presente e do passado. Nesse ponto, cabe marcar o elogio que ele faz a Teófilo Braga, que "julga inutil estabelecer regras em uma grammatica sobre orthografia; mas reconhece sua existencia, como um corpo de doutrinas diverso das outras partes da grammatica" (1887, p. 45). O elogio, e portanto a posição comum, é o de tomar a ortografia enquanto uma parte autônoma da gramática, no que se nota a própria posição de Augusto Freire da Silva de considerar, diferentemente de Teófilo Braga, útil estabelecer regras de ortografia em uma gramática, posições que tocam a questão do conteúdo e, principalmente, da utilidade de uma gramática. Para Augusto Freire da Silva, o lugar das regras da ortografia é na gramática e não fora dela, reconhecendo assim seu estatuto de corpo de doutrina gramatical. Haveria também a posição, que Augusto Freire da Silva sugere ser a de Téofilo Braga, de tomar um estudo sobre a língua como uma doutrina válida, mas não apta a figurar no corpo da gramática. Em suma, para Augusto Freire da Silva, Teófilo Braga acertaria por reconhecer a existência da ortografia como um corpo de doutrinas diverso de outras partes da gramática, mas erraria ao julgar inútil incluir regras sobre ortografia em uma gramática.

Quando aborda o estudo dos vocábulos "como rigorosas palavras, como signaes de nossas idéas", Augusto Freire da Silva estabelece que tais vocábulos são "classificados em especies distinctas, segundo as idéias que enunciam, ou segundo as suas propriedades caracteristicas; ou são combinadas, conforme as suas relações de nexo, de concordancia e de subordinação, em enunciados de juizos ou proposições, que, por sua vez, se entrelaçam, para se formar o periodo composto, ou o enunciado do raciocinio" (1887, p. 45-46). É a partir dessa divisão do estudo dos vocábulos, que denota níveis de formação e de combinação, que Augusto Freire da Silva define a etimologia como "a parte da grammatica que ensina a conhecer a natureza e a origem ideologica das 
palavras"; e a sintaxe como "a parte da grammatica que ensina a coordenar as palavras e as proposições", ao passo que a morfologia como "o estudo das fórmas dos vocabulos" (1887, p. 46). Etimologia e sintaxe, enquanto partes da gramática, são conceituadas a partir de suas funções pedagógicas, como se nota pelo emprego do termo "ensinar".

Augusto Freire da Silva defende que a morfologia "pertence (...) á parte mechanica ou material da grammatica", termo que deve ser adotado "como synonimo de orthografia, visto ter esta parte da grammatica por fim indagar quaes as verdadeiras fórmas graphicas dos vocabulos, considerados em relação com as fórmas dos vocabulos das linguas de que se dirivam" (1887, p. 47). O procedimento de Augusto Freire da Silva é o de fixar a morfologia no campo do que chama de estudo lógico dos vocábulos, no que parece ser uma sugestão de que Júlio Ribeiro coloca indevidamente a morfologia em outro lugar na gramática. Na verdade, o interesse de Augusto Freire da Silva é de pontuar o equívoco da definição de Júlio Ribeiro e também de Teófilo Braga de etimologia, argumentando que "na etymologia o estudo das fórmas dos vocabulos é todo accidental; se se tracta nella das flexões, é por causa das varias idéas, que por meio dellas, exprimem os vocabulos", sendo prova disso o fato de que "um vocabulo póde ter uma só fórma, e ser classificado em mais de uma especie" (1887, p. 46). O erro de Júlio Ribeiro teria sido o de tomar "um termo de significação restrita" e de dar-lhe "a seu talante, uma extensão, que, por fórma alguma, lhe póde caber" (1887, p. 47).

No campo da sintaxe, a crítica de Augusto Freire a Júlio Ribeiro é a de que esse último, ao dividir a sintaxe em sintaxe de palavras e sintaxe de preposições, "nada mais fez que repetir a divisão seguida por Sotero, a qual soube adubar com os termos pomposos de syntaxe lexica e syntaxe logica", alegando ainda que no "uso desta nomenclatura, ainda foi infeliz o sr. Julio Ribeiro, por que syntaxe logica é um pleonasmo grosseiro", não sendo possível "que haja syntaxe que não seja logica; e isto pela simples razão de bazear-se em principios bebidos na logica" (1887, p. 47). No fundo, portanto, Júlio Ribeiro estaria ligado a Sotero dos Reis no estudo da sintaxe, muito embora o primeiro tenha criticado o segundo.

Para Júlio Ribeiro, por sua vez, Augusto Freire da Silva, na explicação sobre a divisão da gramática, deveria aduzir "raciocinios fundados na observação conscienciosa da natureza dos factos linguisticos, na historia das palavras, no seu valor etymologico" (1887, p. 77). Assim, a divisão da gramática em quatro partes seria infundada justamente por não observar esses elementos. 
Na sequência, ao tratar da definição de prosódia, Júlio Ribeiro argumenta que o erro de Augusto Freire da Silva seria justamente o de querer alargar essa significação restrita do termo, abrangendo outros elementos: "Quererá s.s. que um termo de significação restrictissima, que diz respeito sómente á parte musical dos vocabulos, comprehenda, abranja todos os phenomenos phonicos da linguagem?" (1887, p. 78). Júlio Ribeiro defende que a prosódia estuda somente a parte musical dos vocábulos. Na avaliação de Júlio Ribeiro, é um erro de Augusto Freire da Silva dizer que "pensadores deste e de outros seculos têm aceitado" "a significação assim estirada do termo prosodia" (1887, p. 78), o que quer dizer que seriam a favor de uma definição restrita do termo.

Ainda sobre o tratamento da prosódia, Júlio Ribeiro mostra que Augusto Freire da Silva trabalha contra o que ele próprio defende, uma vez que "começa a sua Prosodia tractando dos elementos graphicos das palavras, tractando das lettras..." (1887, p. 81). Dessa forma, para Júlio Ribeiro, Augusto Freire da Silva "tem intuições da verdade, applica-a em parte na pratica, e por espirito de rotina combate-a em theoria" (1887, p. 82). Parece haver aí uma distinção entre procedimento prático e conhecimento teórico, com a ideia que esses dois pontos devem estar em harmonia.

No passo seguinte, Júlio Ribeiro afirma concordar com a definição de morfologia de Augusto Freire da Silva como o estudo das formas dos vocábulos, mas apontando problema na utilização do termo "história" por seu oponente quando esse diz que tal modo de entender a fonologia está em "harmonia com a sua accepção propria na qual significa a historia das fórmas que pode tomar a materia" (1887, p. 82). Logo em seguida, citando Bergman (Resumé d'études d'ontologie générale et de linguistique générale), Júlio Ribeiro afirma que toda palavra é composta por dois elementos, um ideológico e outro formal. Ele explica que o "elemento idéiológico é a concepção da mente, é o fundo, é a parte essencial, é o escopo da Linguagem" ao passo que o "elemento formal é a vestimenta physica, é o meio da Linguagem" (1887, p. 83). Embora Júlio Ribeiro fale de vestimenta física, não se trata fundamentalmente de representação escrita, mas de uma forma material, termo empregado de maneira bastante genérica e que não deve ser confundido com o conceito de forma material tal como trabalhado na Análise de Discurso. Numa referência a Mux Müller ( $L a$ science du langage), Júlio Ribeiro acrescenta que "o elemento idéiologico de uma palavra reside na sua raiz, e que são elementos formaes não sómente as desinencias das declinações e conjugações, mas tambem todas as lettras, todas as syllabas que servem para marcar a derivação" (1887, p. 83). 
Em Júlio Ribeiro, duas das partes da morfololgia, a taxeonomia e a campenomia, parecem observar especificamente o elemento formal da palavra e da linguagem. $\mathrm{O}$ autor toca nesse ponto quando parece considerar como válida a ideia de que a "raiz é elemento idéilogico, não tem que ver com a Morphologia" e pergunta se as desinências como "elementos formaes, têm ou não têm que ver com a Morphologia" (1887, p. 84). A questão de Júlio Ribeiro é, na verdade, saber a origem das desinências: "Mente, por exemplo, será o ablativo latino de mens, como querem os linguistas, ou será vocativo celtico ment como pretendem alguns celtomaniacos?" (1887, p. 84-85). Para Júlio Ribeiro, uma terceira parte da morfologia se ocuparia justamente do "estudo da origem destes elementos formaes" (1887, p. 85), a etimologia ou derivação, numa posição que dá aos elementos formais uma origem, origem essa estabelecida a partir de outra(s) línguas(s), no passado. A morfologia, no fim das contas, na medida em que não trata em suas três partes da raiz, parece jogar para fora de si o estudo do que Júlio Ribeiro chama de elemento ideológico da palavra e da linguagem. Também aqui não se deve confundir o emprego que Júlio Ribeiro faz do termo ideologia com o modo como o conceito é trabalhado na Análise do Discurso.

Em posição que se diz contrária aquela de Augusto Freire da Silva, Júlio Ribeiro defende que o som é uma forma material, capturada pelo ouvido, a exemplo do gráfico, capturado pelo olho: "Com que então só é fórma material o que é graphico, o que é accessivel ao sentido da vista. O que impressiona o ouvido não o é?" (1887, p. 86). A questão é a da natureza da forma material, no que se inclui a questão de sua a captação, no corpo humano, de forma que Júlio Ribeiro parece falar de matéria enquanto matéria sensível.

Confirmando que seguiu a divisão da sintaxe de Sotero dos Reis, Júlio Ribeiro recorre à etimologia e ao uso histórico do termo lógica para responder à crítica de Augusto Freire da Silva de que teria sido infeliz no uso da nomenclatura e cometido um pleonasmo ao falar de sintaxe lógica: "Logiké em Grego não é substantivo, é a terminação feminina do adjectivo Logikós, logiké, logikón, que significa pertencente á falla, ao discurso em prosa; oppõe-se a Poeitikós, ou a Mousikós." E continua: "Foi nesse sentido que o empregou Diogenes Laerte, escriptor grego do seculo III (...). Para que Logiké signifique arte de pensar é preciso que se subtenda o substantivo Tekhné (arte)" (1887, p. 87). Em sua defesa, Júlio Ribeiro explica que, quando fala em sintaxe lógica, o qualificativo lógica "não deriva do nome da arte de pensar; mas sim, que o nome da arte de pensar é que se deriva do qualificativo empregado por mim" (1887, p. 88). 


\section{Orientação teórica da gramática}

No estudo dos termos sentença e período, quando defende que é preciso tomar os ingleses para mestres (daí sua preferência, como vimos, pelo termo sentença), Júlio Ribeiro critica prontamente a posição de Beauzée e Girault-Duvivier no tema por seus "dislates metaphysicos" e pedindo à "physiologia alguma cousa menos nebulosa sobre a linguagem articulada" (1887, p. 25). Está aí mais uma das várias vezes em que Júlio Ribeiro vai criticar a metafísica em sua obra, ou melhor, em que vai usar o termo metafísica para caracterizar negativamente um modo de refletir sobre a linguagem. Ao invés da metafísica, Júlio Ribeiro sugere seguir a fisiologia no estudo da linguagem articulada. Se, como já se tornou comum dizer, Júlio Ribeiro contrapõe regularmente metafísica e ciência, temos aí a fisiologia assumindo a posição da ciência, sendo colocada em superioridade sobre a metafísica para o tratamento correto da linguagem articulada.

Augusto Freire da Silva se apresenta nesse debate, afirmando ter procurado se apropriar da "verdadeira doutrina" "da grammatica e lingua nacional" e dizendo ter a "convicção de ter acompanhado o progresso da sciencia, e de ensinar o que nella ha de melhor" (1887, p. 37). O que se disputa, como se pode antever, é a apropriação da verdadeira doutrina, é saber quem tem verdadeiramente acompanhado o progresso da ciência, é determinar o que pode ser chamado de ciência e quem se coloca legitimamente ao lado dela. O que está em jogo é, na verdade, a consideração de quem trata de maneira científica a gramática e a língua nacional. São dois lados que disputam esse lugar, jogando o oponente para fora do campo da ciência, como se fossem duas posições incompatíveis, e como se apenas uma fosse correta.

Augusto Freire da Silva escreve que "o sr. Julio Ribeiro, refutando doutrinas que de longa data fizemos nossas, que exceptuados os srs. Adolpho Coelho, Theophilo Braga e Pacheco Junior, estão todos os mais em erro na sciencia grammatical, desde o fiat lux do Padre Eterno" (1887, p. 37). Por Augusto Freire da Silva falar em "sciencia grammatical", e lembrando que Júlio Ribeiro havia afirmado que a gramática é a ciência da linguagem, poderíamos dizer que há uma certa concordância entre os dois autores do estatuto científico da gramática, mas ao mesmo tempo uma disputa de qual maneira de fazer gramática é a científica, uma forma de dizer que, embora a gramática seja uma ciência, nem toda forma de fazer gramática é científica, ou que a gramática é uma ciência desde que seja feita de uma determinada maneira. 
Sobre suas ligações com a gramática de Sotero dos Reis, Augusto Freire da Silva argumenta que "qualquer espirito desprevenido, que as cotejar, verá que na nossa ha muita cousa que não se encontra na de Sotero, se bem que nos tenhamos apropriado de muitas das suas opiniões" (1887, p. 38). Nesse sentido, manifesta que "tanto é o respeito que votamos á memória de Sotero, nosso mestre de outr'ora no Lyceu de S. Luiz do Maranhão, que sentimo-nos honrado com o asserto do sr. Julio Ribeiro, em que nos considera repetidor de suas doutrinas" (1887, p. 38-39). Augusto Freire da Silva estabelece portanto o traçado de suas filiações com Sotero dos Reis, reconhecendo sua existência, mas apontando seus limites. Assim, se não seria uma ofensa ligá-lo a Sotero dos Reis, seria uma imprecisão afirmar que ele faz apenas a repetição do que disse o outro. Haveria, portanto, um espaço de autoria, uma posição em que os dois até podem ser ligar, mas não se confundem.

É interessante a homenagem que se faz a Sotero dos Reis, chamado de "mestre de outr'ora no Liceu de S. Luiz do Maranhão", o que mostra o lugar de destaque do autor entre os gramáticos maranhenses, dos quais se fala ainda muito pouco, muito embora estivessem ainda em plena atividade no momento em que a produção gramatical é introduzida em São Paulo e Rio de Janeiro. A crítica que os gramáticos de São Paulo e Rio de janeiro fazem a esse grupo, negando sua importância por eles estarem supostamente ligados a uma metafísica e, portanto, sem valor científico, parece ter sido incorporada de certa maneira na história das ideias linguísticas no Brasil, como se a produção gramatical no final do século XIX se reduzisse a São Paulo e Rio de Janeiro. A nosso ver, existem outras escolas de gramáticos no país que estão ainda a ser consideradas e estudadas, como aquela do Maranhão.

Para Augusto Freire da Silva, o "confronto da grammatica de Francisco Sotero dos Reis com a de Jeronymo Soares Barbosa repelle por si só a inverdade do que sobre estes dous grammaticos diz o topico mencionado" (1887, p. 39) por Júlio Ribeiro, isto é, de que um repetiu o outro, ou mais precisamente, de que um repetiu o que o outro disse sobre a divisão da gramática em quatro partes, o tratamento da etimologia e sintaxe, a determinação da quantidade de espécies de palavras, a nomenclatura e, de forma geral, doutrinas, estilo, divisão da sintaxe:

Soares de Barbosa tractou detidamente das quatro partes da grammatica; ao passo que Sotero cuidou mais da etymologia e syntaxe. Aquelle, admittindo na etymologia apenas seis especies de palavras, tem na maior parte dos casos uma nomenclatura e doutrinas todas suas ; este classifica as palavras em oito especies, 
e adopta, com leves differenças, a terminologia geralmente acceita. O primeiro sobre uma linguagem árida e ás vezes abstrusa, tem opiniões inteiramente avessas ás de Sotero dos Reis, que prima pela clareza, e por um estylo ameno e agradavel. O grammatico portuguez divide a syntaxe em syntaxe propriamente dita e em construcção; e subdivide aquela em syntaxe de concordancia e de regencia tractando ao mesmo tempo do que é referente ás palavras e ás proposições, e esta em construcção directa, invertida e interrupta, além de adoptar uma doutrina sobre as proposições deficiente e sumamente complicada; entretanto que pelo grammatico maranhense é o estudo da syntaxe desenvolvido sob um plano inteiramente novo, pois dividiu-a em syntaxe de palavras e de proposições, explanando naquella a collocação das palavras, e nesta a das proposições, sob as relações que entre umas e outras se dão, e isto por modo muito diverso do dos outros grammaticos, e em certos respeitos até com innovação. Se descessemos a uma analyse circumstanciada destas duas grammaticas, differenças mais palmares teriamos de notar, as quais não podem ser adduzidas em um trabalho como este, feito ao correr da penna". (1887, p. 39-40)

No trecho acima, vemos uma distância estabelecida não apenas entre Soares Barbosa e Sotero dos Reis, ou entre Sotero dos Reis e o próprio Augusto Freire da Silva, na medida em que esse último admite uma certa filiação com Sotero dos Reis, mas principalmente uma distância entre o gramático brasileiro e o gramático português, entre a gramática brasileira e a gramática portuguesa, com um julgamento favorável da primeira em detrimento da segunda. É contundente na redação de Augusto Freire da Silva o elogio da instauração do novo por parte de Sotero dos Reis, um gramático que não trabalhava com a gramática histórica e comparada. Essa inovação se daria em relação a Portugal, e também em relação a outros gramáticos brasileiros, no caso específico do tratamento da sintaxe de palavras e de proposições. Há uma observação das prioridades de cada lado: o português trata das quatro partes da gramática, o brasileiro prioriza a etimologia e a sintaxe. Do lado do português, a inovação é tomada negativamente: o português se isola em suas doutrinas, enquanto o brasileiro, quando se põe dentro de uma tradição, emprega uma terminologia aceita, reconhecida, portanto, correta. O português se exprime da maneira árida e abstrusa, com uma doutrina deficiente e complicada, ao passo que o brasileiro prima pela clareza e pelo estilo agradável, numa doutrina que, sendo contrária àquela do português, só poderia não ser deficiente e simples.

Respondendo à crítica de Júlio Ribeiro de que se aduba com "muita subtileza soporifica um mixtiforio de orações absolutas, principaes, approxi- 
madas, incidentes, integrantes, restrictivas, explicativas", Augusto Freire da Silva replica que o "modo manco, por que se acha feita esta nomenclatura da theoria das proposições, dá logar a não saber ao certo qual seja o gramático, para quem foi talhada a carapuça" $(1887$, p. 51$)$, no que se nota que a questão em jogo é justamente a da nomenclatura da teoria das proposições, pelo menos é dessa forma que Augusto Freire da Silva nomeia o problema. Em todo caso, uma vez mais a questão da nomeação dos elementos gramaticais se faz presente no debate, com críticas de ambos os lados de que a nomenclatura é feita de maneira errônea, numa posição que aponta portanto para a afirmação da existência de uma forma correta de estabelecer a nomenclatura gramatical. Para Augusto Freire da Silva, portanto, é Júlio Ribeiro quem trata de maneira errada a nomenclatura das proposições.

Para Augusto Freire da Silva, por falar em "orações absolutas e approximadas, expressões de que, em grammaticas portuguezas, só usou Sotero, ou aquelles que têm seguido suas opiniões, parece-nos que allude o sr. Julio Ribeiro á divisão das proposições, adoptadas por este grammatico" (1887, p. 51). Um ponto a marcar dessa passagem é o fato de Augusto Freire da Silva falar de gramáticas portuguesas e não de gramáticas brasileiras, muito embora esteja explicando o trabalho de dois gramáticos brasileiros, Sotero dos Reis e o próprio Júlio Ribeiro. O gramático é brasileiro, mas a gramática é portuguesa, o que nos remete à observação de Orlandi e Guimarães (2001, p. 27) de que o título das primeiras gramáticas brasileiras "funciona a partir de uma posição de denominação que marca a relação com Portugal”. Um outro ponto a marcar é a definição de uma proeminência de Sotero dos Reis por usar terminologias que são seguidas por aqueles que fazem gramáticas portuguesas, a observação de uma especificidade de uma nomenclatura gramatical utilizada por uma linha de gramáticos que passa e se orienta por Sotero dos Reis. Tal proeminência se dá por ter sido o único entre as gramáticas portuguesas a usar certas expressões; não apenas o único mas também o primeiro, já que Sotero dos Reis fez seguidores, entre eles o próprio Augusto Freire da Silva, que se incube a obrigação de defendê-lo por segui-lo de longa data, ou mais precisamente de defender a divisão das proposições feita por Sotero dos Reis: "Estamos, pois, na obrigação de defendel-a, por acceitarmol-a, ha muito tempo" (1887, p. 51). Em resumo, o lugar reivindicado por Augusto Freire da Silva é o de autores de gramáticas portuguesas que têm seguido as opiniões de Sotero dos Reis.

Augusto Freire da Silva procura aproximar o trabalho de Sotero dos Reis do de Noël e Chapsal, Poitevin, Girault-Duvivier e Téofilo Braga no tocante à divisão das proposições, buscando mostrar que a divisão, e mesmo a 
nomenclatura, das proposições de Sotero dos Reis é amplamente empregada. Assim, ele argumenta que as "proposições que Sotero chama absolutas são as mesmas que Noël e Chapsal chamam principaes, que são por estes subdivididas em principaes absolutas e principaes relativas, e por aquelle em absolutas principaes e absolutas approximadas", de modo que a "unica differença que ha entre estas duas opiniões, está nos termos que adoptaram, para designarem esta especie de proposições; na substancia a doutrina é a mesma" (1887, p. 52). A única diferença marcada entre Sotero dos Reis e Noële Chapsal é a adoção dos termos, uma diferença não substancial, contudo, uma vez que a doutrina seria a mesma, com todos trabalhando as divisões e subdivisões de maneira igual. Pode-se portanto empregar termos diferentes para defender a mesma doutrina, isto é, a diferença de nomenclatura não determina uma diferença de posição teórica, postura essa que dissocia termos e opinões, terminologia e doutrina. Nesse posicionamento, que não é simplesmente gramatical, mas de verdadeira ordem epistemológica, a identidade da doutrina não se determina pelo aspecto da terminologia, a substância da doutrina não é de ordem terminológica, uma vez que a terminologia pode variar.

Após mostrar a similitude entre Sotero dos Reis e Noël e Chapsal, num questionamento que se direciona às críticas de Júlio Ribeiro, de forma a invalidá-las, Augusto Freire da Silva pergunta se esses gramáticos franceses são irracionais, se "terão feito esta classificação com toda a irracionalidade", afirmando logo em seguida abonar a posição deles: "Eu abono delles, falla bem alto o numero de edições que tem tido sua grammatica" (1887, p. 52). Augusto Freire da Silva seguiria, portanto, a racionalidade da classificação das proposições segundo Sotero dos Reis e Noël e Chapsal, racionalidade essa comprovada pelo sucesso editorial da obra dos franceses, numa sugestão de que são muitos os seus seguidores.

Augusto Freire da Silva inclui também Poiteven, Girault-Duvivier entre os seguidores da divisão racional das proposições: "Esta opinião é ainda seguida por Poitevin. Não citamos a Girault Duvivier, que tambem a adoptou, de receio de molestar o sr. Julio Ribeiro", acrescentando ainda Teófilo Braga ao afirmar que "não nos podemos furtar ao prazer de citar o sr. Theophilo Braga, auctor dilecto do sr. Julio Ribeiro, que segue a mesma doutrina" (1887, p. 53) e, em seguida, que para "sustentarmos a doutrina das subordinadas, não é preciso muito. O mesmo sr. Theophilo Braga encarrega-se disso" (1887, p. 53). Augusto Freire da Silva parece sugerir que Júlio Ribeiro, através de Girault-Duvivier e Teófilo Braga, estaria ligado a uma rede de autores que trabalham com a doutrina das proposições da mesma forma que o autor que ele criticaria, 
Sotero dos Reis. Seria como se, no fim das contas, Júlio Ribeiro e Augusto Freire da Silva seguissem a mesma doutrina, a qual chegariam por caminhos diferentes, ou para ser mais justo, como se Júlio Ribeiro não percebesse que, tendo Teófilo Braga como autor dileto, compartilha da doutrina de Sotero dos Reis. Em todo caso, o que se nota bem é a ideia da filiação entre autores brasileiros, portugueses e franceses. Augusto Freire da Silva fala certamente de M. P. Poitevin, que escreveu em 1856 uma Grammaire générale et historique de la langue française. Anos antes, em 1811, Girault-Duvivier havia escrito sua Graimmaire des grammaire ou analyse raisonnée des meilleurs traités sur la langue française. No meio tempo, em 1823, Noël e Champson, na verdade, Charles-Pierre Chapsal e François Noël, escreveram em conjunto a Nouvelle grammaire française avec exercices. É a partir de Teófilo Braga, um autor mostrado como relacionado a Júlio Ribeiro, que Augusto Freire da Silva valida a doutrina das subordinadas, invalidando a crítica daquele a Sotero dos Reis, uma vez que ele aclamaria Teófilo Braga, autor que estaria na mesma linha que Sotero dos Reis e Augusto Freire da Silva no tema em questão. É nesse sentido que Augusto Freire da Silva compara o trabalho de Teófilo Braga ao de Auguste Brachet:

Repetindo o que disse o sr. Auguste Brachet, na sua Nouvelle Grammaire Française, sobre a qual calcou a sua Grammatica Portugueza Elementar, admitte o sr. Theophilo Braga, com toda racionalidade, proposições subordinadas, que subdivide em completivas ou indispensaveis e circumstanciaes; e de que, como especies, apresenta as proposições participio, as infinitivas, as conjunctivas, as relativas, que são o mesmo que as incidentes, já explicativas, já restrictivas, e as integrantes; se bem faça dellas um verdadeiro mixtiforio, porque não descrimina as que são subdivisões das circumstanciaes, das que o são das completivas (1887, p. 53-54).

Na comparação do tratamento da divisão das proposições em Teófilo Braga e Auguste Brachet, afirmando que o primeiro repete e calca sua gramática sobre a do segundo e julgando que, a exemplo do autor francês, o português assume uma posição racional, Augusto Freire da Silva traz uma vez mais à tona a ideia de que o fundo de uma doutrina não depende da terminologia, uma vez que ele mostra justamente que, ao dividir as proposições da mesma maneira, apesar da utilização de termos por vezes diferentes, Auguste Brachet é seguido por Teófilo Braga, ainda que esse último, e a despeito disso, cometa uma mistura e confusão no tratamento do tema. No fundo, a doutrina é a mesma. Doutrina 
essa avaliada segundo um critério que já havia aparecido anteriormente na argumentação de Augusto Freire da Silva, o da racionalidade, como se reforçasse a ideia de que o tratamento correto da doutrina gramatical se faz segundo a égide da racionalidade, ou melhor, de que o tratamento da doutrina gramatical é correto quando é racional. Assim, lembrando que Teófilo Braga, segundo a avaliação de Augusto Freire da Silva, trabalharia de forma racional ainda que misture elementos, poderíamos dizer que a terminologia, e num ponto mais sutil a organização, não demole uma doutrina gramatical. É justamente falando de doutrina que Augusto Freire da Silva defende o que chama de princípios inconcussos da doutrina de Sotero dos Reis sobre as proposições:

A doutrina das proposições, abraçada por Sotero, e por elle brilhantemente explicada, em que peze ao sr. Julio Ribeiro, assenta em principios inconcussos, visto como, pela ordem, geração e successão natural das idéas, o periodo composto, ou consta só de proposições absolutas, que, por enunciarem juizos absolutos ou independentes entre si, ligam-se, sem exercerem umas nas outras influencia alguma, e sem se dar entre ellas regra alguma particular de syntaxe; ou consta de proposições absolutas e subordinadas, sendo estas das que dependem, ou simples circumstanciaes, ou partes essenciaes. $(1887$, p. 54$)$

Sotero dos Reis aparece como aquele que abraça e explica uma teoria que se assenta em princípios solidamente estabelecidos e que, portanto, não se deixaria abalar por eventuais equívocos terminológicos ou de organização, como os que teriam sido cometidos por Téofilo Braga. Na sequência, e em consequência do que foi exposto, Augusto Freire da Silva defende a necessidade de conhecer uma teoria filosófica para trabalhar o período composto: "Sem o conhecimento de uma theoria perfeita e summamente philosophica, como esta, não se póde tecer bem o periodo composto; e isso porque, por meio della, é que conhecemos as relações de nexo, concordancia e dependência, em que estão umas proposições para com outras" (1887, p. 54-55). Augusto Freire da Silva acaba por estabelecer uma relação entre teoria filosófica e tratamento gramatical, entre filosofia e gramática, sendo a teoria filosófica a base do tratamento gramatical, ou melhor, sendo a perfeição da teoria filosófica a garantia do bom trabalho gramatical. Dessa forma, o desconhecimento da teoria filosófica, de base filosófica, teria consequências negativas: "O seu desconhecimento, ao envez, é que tem dado logar a nos classicos encontrarem-se periodos incompletos, ou construídos por um modo todo enrevesado; e a muitas vezes usarem mal dos signaes de pontuação, mormente do ponto e vírgula e dos dous pontos" (1887, p. 55). A 
prática de pontuar corretamente está subordinada ao conhecimento das relações sintáticas, que, por sua vez, estão determinadas pela teoria filosófica. Um ponto a notar é o julgamento de que faltava aos clássicos o conhecimento da teoria filosófica, falta essa que teria levado a falhas, incompletudes, enviesamentos.

Para mostrar como faz todo sentido falar em princípio geral e princípio particular, Augusto Freire da Silva apela inclusive à lógica, "onde se ensina que, no raciocinio por inducção, se parte de um principio particular para um geral, como, por exemplo, depois de haver observado o peso de muitos corpos, se conclue que todos os corpos são pesados" e que "no raciocinio por dedução, se parte de um principio geral, para um particular, como quando de uma lei da natureza, ou um axioma mathematico, se chega a uma de suas applicações" (1887, p. 62).

Em resposta a Augusto Freire da Silva, Júlio Ribeiro afirma não contestar as diferenças existentes entre a gramática daquele e de Sotero dos Reis, reconhecendo inclusive que, como teria afirmado Augusto Freire da Silva, mesmo "Sotero dos Reis e Soares Barbosa divergem em varias pontos, que têm opiniões avessas entre si, que tractam com desenvolvimento desigual esta ou aquella parte da grammatica, que a linguagem de um é abstrusa, que o estylo de outro é ameno, etc." (1887, p. 68-69). O ponto de contestação não seria a própria existência de semelhanças entre Augusto Freire da Silva, Sotero dos Reis e Soares Barbosa, como se estivessem errados pelo simples fato de repetirem um ao outro, mas a convergência em um ponto falho, isto é, o modo de concepção da gramática:

No que o sr. dr. Freire repete a Sotero, Sotero a Barbosa, Barbosa a Lobato etc. etc. é no modo de conceber a grammatica como uma disciplina arida, auctoritaria, dogmatica; como uma instituição metaphysica existente a parte rei, como uma essencia universal do realismo escolastico; é em dividil-a irracionalmente em quatro partes; é em não discriminar os factos nas divisões; é em definir erradamente os mesmos factos; é em não aplicar o seu estudo o methodo natural, o criterio scientifico, a analyse comparativa; é em não descobrir vida nos organismos lexicos; é em não demonstrar nessa vida o cumprimento fatal da lei da evolução, da lucta pela existencia, e a influencia profundamente modificadora do meio climatologico, do meio social; é, emfim, em estudar a gramática hoje mais desastradamente do que era ella estudada no tempo de Aristoteles, ha mais de vinte e dois seculos. (1887, p. 69) 
Para Júlio Ribeiro, portanto, diferentemente do que seria para uma linha de gramáticos que vai de Lobato, em Portugal, a Augusto Freire da Silva, no Brasil, a gramática não é uma disciplina árida, autoritária nem dogmática, não sendo também uma instituição metafísica ou uma essência universal do realismo escolástico. Assim, por pensarem de forma contrária, de maneira irracional, os gramáticos apontados dividiriam a gramática de maneira igualmente irracional, em quatro partes. Para combater essa ideia, Júlio Ribeiro chama a atenção para os procedimentos que devem ser empregados na divisão da gramática, afirmando ser preciso definir corretamente os fatos. Para tanto, no estudo da gramática, seria igualmente necessária a aplicação do método natural, do critério científico e da análise comparativa. $\mathrm{Na}$ articulação entre esses elementos, colocados no mesmo patamar e significados mutualmente entre si, Júlio Ribeiro dita uma vida para os organismos léxicos, nomeação fortemente comprometida com aqueles três elementos trazidos pelo autor, evocando uma outra necessidade, a de demonstrar nessa vida dos organismos léxicos o cumprimento da evolução, significada como uma lei fatal, uma lei que diz respeito à luta pela existência e à influência do meio climatológico e do meio social, influência essa da ordem da modificação, da mudança. Cabe notar que esse grande valor dado ao meio social na evolução vai ser uma constante na obra de Júlio Ribeiro. Cabe notar ainda, no trecho acima, o desenho de uma temporalidade no estudo da gramática, sendo ela datada em mais de vinte séculos e ligada em suas origens a Aristóteles. O desenho dessa temporalidade é, na verdade, a enunciação de um passado e de uma tradição que devem ser superados, discurso no qual Júlio Ribeiro provoca seus opositores ao afirmar que eles estudam mais desastradamente a gramática do que no tempo de Aristóteles, no que se vê a ideia de que já se estudava desastradamente a gramática naquela época. Pode-se dizer que a superação se daria exatamente pela aplicação da lei da evolução à gramática. É ela, a lei da evolução, a nova, a melhor e a correta fase dos estudos gramaticais.

Na sequência, Júlio Ribeiro coloca Augusto Freire da Silva, Sotero dos Reis e Lobato como exemplos de discípulos de Pedro Sanchez e Júlio César Scaligero que "seguem as pisadas dos mestres, e perdem-se em abstracções, divagando em torno da verdade sem nunca attingil-a", sendo acusados especificamente de tirarem dos "solitarios de Port Royal" a "concepção falsa" de fazer "consistir na affirmação a idéia capital do Verbo" (1887, p. 69-70). Para Júlio Ribeiro, a Grammaire Générale et Raisonée foi a primeira a definir o verbo como uma palavra que significa a afirmação, definição essa considerada injustificável. Assim, de acordo com Júlio Ribeiro, Augusto Freire da Silva no tratamento do verbo segundo Port-Royal, faz “confusão de idéias e de palavras” (1887, p. 71). 
Tal erro, segundo Júllio Ribeiro, seria também cometido por Soares Barbosa, o que mostra bem que o problema do tratamento do verbo enquanto afirmação é a confusão entre ideias e palavras. Assim, numa referência à Grammatica Philosophica, Júlio Ribeiro afirma que Soares Barbosa "attribue sómente ao indicativo a affirmação", argumentando que "appliquem-se-lhe á doutrina os mesmos raciocinios mutatis mutandis, e ver-se-á que o erro é o mesmo, embora mais restricto" (1887, p. 72).

Além da definição do verbo como afirmação, um outro ponto condenado Júlio Ribeiro é o da formulação de regras sobre o emprego do infinitivo pessoal e impessoal, sentenciando que Augusto Freire da Silva, Sotero dos Reis e Soares Barbosa formularam "uma regras que, benza-as Deus, deram resultados muito chinfrins" (1887, p. 72), "De que não será capaz a metaphysica" (1887, p. 73), pergunta Júlio Ribeiro, para quem esses são portanto erros da metafísica, são erros cometidos por um tratamento metafísico da formulação de regras, uma forma de dizer que as regras não devem ser formuladas de maneira metafísica, pois a metafísica leva ao erro. Para Júlio Ribeiro, antes o silêncio do que a metafísica, pois com o silêncio há menos chances de errar: "Bem fez Lobato que sobre usos de infinito pessoal não disse palavra" (1887, p. 73). Em oposição à metafísica, é a obra de Diez que é indicada por Júlio Ribeiro para aprender o uso correto dos infinitivos portugueses: "As regras acham-se no terceiro volume da Grammatica das Linguas Romanicas, pag. 202” (1887, p. 73). É interessante notar esse recurso a um autor estrangeiro para o aprendizado dos usos do português. O mais importante, porém, é perceber essa imagem que Júlio Ribeiro faz de uma categoria que ele chama de gramáticos metafísicos como inventores de regras que são contrárias ao gênio dos idiomas:

Antes de passar além, os grammaticos metaphysicos são mesmo uns homens levadinhos da breca: vimos ha pouco o desplante com que Sotero, Barbosa et reliquia foram acoimar a Camões de incorrecto. E'velha a balda de inventar regras para depois abitolar por ellas escriptores que as não conheceram, e que, quando as conhecessem, as não praticariam, por serem ellas contrarias ao genio dos idiomas de que serviam elles. O bom do Roboredo tambem teve para si que Sanchez era mais entendido na póda em materia de latinidades do que Cicero e Varrão. «De estar a Latina (grammatica) reduzida a arte ha tantos annos, escreveu o homme, e ir-se sempre aperfeiçoando, podemos dizer que soube Francisco Sanchez Brotense mais grammatica em nossos tempos que Cicero e Varrão, columnas da lingua, nos seus que lhe precederam 1640 annos». (1887, p. 73-74) 
A ideia parece ser a de que é preciso trabalhar em harmonia como gênio do idioma, uma vez que, como demonstraria a metafísica, ir contra o gênio do idioma conduz a erros. Nesse aspecto, os escritores (como Camões) aparecem como aqueles que escrevem segundo o gênio dos idiomas, isto é, de que as regras praticadas pelos escritores seguem o gênio do idioma. Dessa forma, enquanto o gramático formula e inventa as regras, o escritor é aquele que segue as regras, mas não qualquer gramático, e sim o gramático que não é metafísico.

Quando acusa Augusto Freire da Silva de erro ao não entender que a ortografia faz parte da fonologia, Júlio Ribeiro defende que "a Orthographia faz parte da Phonologia, e que não pôde constituir divisão independente da Grammatica, é cousa assente entre os linguistas hodiernos" $(1887$, p. 80). Temos aí uma questão gramatical respondida pela linguística, com a linguística como um argumento forte e talvez definitivo para o tratamento gramatical. Se antes Júlio Ribeiro falava negativamente em gramáticos metafísicos, ele apresenta agora com toda estima os linguistas modernos, o que nos faz pensar que haveria aqueles que não seriam modernos. Assim, o conhecimento gramatical ganha respaldo pelo conhecimento linguístico, ou melhor, significa como correto quando coincide com os resultados do conhecimento linguístico. Nesse sentido, os gramáticos deveriam se afastar dos gramáticos metafísicos e se aproximarem dos linguistas modernos. Quem são os linguistas modernos? Na avaliação de Júlio Ribeiro, tudo o que ele vem apresentando são as "theorias" "maes ou menos" "seguidas por Max Müller, por Whitney, por Coelho, por Guardia e Wierzeyski, por Bréal, por Pacheco Junior, por todos os linguistas modernos" (1887, p. 85).

Sobre a crítica de Augusto Freire da Silva de que, ao dividir a sintaxe em sintaxe de palavras e sintaxe de proposição, Júlio Ribeiro teria repetido a divisão de Sotero Reis, adubando-a com os termos pomposos de sintaxe léxica e sintaxe lógica, o autor responde que "a terminologia scientifica hodierna é toda tirada do Grego: eu andei com a moda, fiz como Hæckel, pilhei da cozinha grega os meus adubos" (1887, p. 86), o que demonstra que o problema em questão para Júlio Ribeiro é o do fundo terminológico do estudo gramatical.

Após caracterizar o ensino oficial como antiquado e ultrapassado, Júlio Ribeiro se volta para Augusto Freire da Silva afirmando que ele "em materia de linguistica e de gramática, está atrazado cem annos ou mais" (1887, p. 89). No fim das contas, o atraso de que fala Júlio Ribeiro é o do ensino de gramática e de linguística, consideração na qual se percebe a ideia de que houve mudanças nessas disciplinas no século XIX, mudanças essas que não teriam sido acompanhados por autores como Augusto Freire da Silva nem incorporadas no ensino oficial. Júlio Ribeiro parece colocar entre esses avanços do estudo da 
linguística e da gramática o tratamento da natureza da linguagem articulada e da enunciação do juízo, pois ele declara que Augusto Freire da Silva supõe que "a linguagem articulada, producto da evolução do cerebro humano, funda-se em principios invariaveis, existentes metaphysicamente ab eterno", argumentando em seguida que o gramático maranhense ignora que "o enunciado do juizo por meio de um sujeito, de um verbo e de um predicado não é, e nem póde ser facto de eterna verdade, que tal enunciado é uma fórma MERAMENTE TRADICIONAL" (1887, p. 89-90). Assim, para Júlio Ribeiro, a linguagem articulada não se funda em princípios invariáveis, sendo antes um produto da evolução do cérebro humano, forjada pela evolução e não por princípios metafísicos, e consequentemente poderíamos emendar, devendo ser estudada não pela metafísica, mas segundo a teoria da evolução. Duas posições se colocam na definição da linguagem articulada, uma que a tomaria como uma existência metafísica, a que Júlio Ribeiro aponta ser de Augusto Freire da Silva, e a que a tomaria como produto da evolução, a que Júlio Ribeiro defende como verdadeira.

A ideia que defende Júlio Ribeiro é de que falar "no arbitrio dos povos em questões de linguistica", tal como teria feito Augusto Freire da Silva, é uma "ignorancia de biologia, de anthropologia, de mesologia", pois em "em todas as relações de viver sociologico nada ha de arbitrario, de livre: tudo depende da evolução fatal do cerebro e da influencia do meio", sendo que a "evolução linguistica é producto necessario de leis inexoraveis, inquebrantaveis" (1887, p. 90), numa reiterada referência ao livro Science du langage de Max Müller. Como se nota mais uma vez, falar em tradição não constitui um problema para Júlio Ribeiro. Antes, se não era possível falar em princípios universais, o que se censura agora é falar de arbítrio.

Cabe notar a linguística colocada como uma área que deve observar os conhecimentos da biologia, da antropologia e da ecologia sob o risco de fornecer informações e análises ignorantes, por assim dizer. A linguística se nutria assim de forma benéfica dessas áreas, estando a elas ligada. Existe uma determinação de ordem linguística, correspondente a uma determinação de ordem sociológica, numa explicação que põe a linguística dentro de um grande domínio do viver sociológico, viver esse dependente da evolução incontornável do cérebro e da influência do meio. É justamente por estarem submetidos à evolução do cérebro e à influência do meio que os povos não são livres em questão de linguística nem em qualquer outra relação do chamado viver sociológico. Nada é arbitrário pelo simples fato de nada escapar à evolução e ao meio.

A questão para Júlio Ribeiro é a da confusão entre princípios e fatos, confusão essa responsável "a dar em resultado a ridicula expressão - principio 
particular" (1887, p. 90) empregada por Augusto Freire da Silva. De acordo com Júlio Ribeiro, "este desconchavo attentatorio do bom senso é condemnado pelas definições dos lexicographos, é garrotado até pela suada e estafadissima logica, que ensina que na inducção parte-se de factos para se chegar a principios" (1887, p. 91), afirmação que reivindica uma explicação lógica que coloca os fatos como uma espécie de ponto de partida e os princípios como ponto de chegada e que coloca a lexicografia em corcordância com essa explicação lógica. Como já havia feito Augusto Freire da Silva, Júlio Ribeiro recorre à lógica para resolver uma questão linguística, mas dando uma explicação completamente diferente. Pela lógica da indução, Júlio Ribeiro define os princípios como algo que se desenrola dos fatos, procurando separar princípios e fatos e negar a possibilidade de falar em princípio particular.

Júlio Ribeiro argumenta que o seu fim é o de "mostrar que o ensino official, cathedratico, privilegiado já não póde mais, sem estribar-se na sciencia, oppôr-se ao tentamen dos que acompanham o século, dos que querem ser úteis á causa do progresso, que é a causa da humanidade" (1887, p. 91). No Brasil, por não seguir os cientistas modernos, o ensino oficial é um entrave ao progresso, numa ideia positivista que liga educação e progresso, que considera que o progresso é atingido por meio da educação, educação que, para levar ao progresso, deve se apoiar na ciência. Cabe notar que o termo catedrático é recorrentemente empregado por Júlio Ribeiro para tratar, não sem deboche, Augusto Freire da Silva, no que parece ser um modo de marcar uma posição de atraso das teorias por ele defendidas. Na verdade, segundo o próprio Júlio Ribeiro, o que ele atacaria seriam "theorias escolastico-metaphysicas, theorias adoptadas e peioradas por Sotero dos Reis, e sahiu-me pela frente o sr. dr. Augusto Freire da Silva, Professor Cathedratico de Portuguez na Faculdade de S. Paulo" (1887, p. 92). Assim, bem longe de ser um signo de distinção ou de um tratamento respeitoso, o emprego constante de "sr. dr." e de "professor catedrático" para se referir a Augusto da Freire é uma maneira de mostrar como ele e suas teorias estão atrasados, não acompanhando o século, não se apoiando na ciência, não contribuindo com o progresso e com a humanidade, mas promovendo antes um entrave.

Numa nota de rodapé ligada à afirmação de que Sotero dos Reis adotou e piorou teorias escolástico-metafísicas, Júlio Ribeiro transcreve a definição de gramática particular de Du Marsais ("La Grammaire Particulière est l'art de faire concorder les principes immuables et généraux de la parole prononcée ou écrite AVEC LES INSTITUTIONS arbitraires et usuelles d'une langue particulière") indicando que ela é reproduzida por Girault-Duvivier e, em seguida, 
exibe a definição de gramática particular dada por Sotero dos Reis ("Grammatica Particular é a arte de applicar AOS PRINCIPIOS IMMUTAVEIS e geraes da palavra AS INSTITUIÇÕES arbitrarias e usuaes de qualquer lingua"), mostrando assim uma semelhança entre Sotero dos Reis, Girault-Duvivier e Du Marsais no emprego de teorias escolástico-metafísicas na definição de gramática particular. Augusto Freire da Silva é pintado nesse quadro como alguém que aparece com "affirmações infundadas, robustecidas apenas por sua respeitavel assignatura; com gracejos charros; com adjectivos maldosos; com citações vagas, e na mór parte da surrada matula expulsa já do templo da ciência" (1887, p. 92). "Responder, profligando a insciencia, é mais do que o meu direito, é o meu dever", declara Júlio Ribeiro, emendando rapidamente o seguinte: "Vejo, porém, que perco o meu trabalho em rasgar a s.s. o horizonte das idéias novas: a assimilação dessas idéias não se faz de jacto, exige annos de digestão" (1887, p. 92-93), numa descrição de um modo de construção e de operação da ciência pela expulsão de ideias antigas e assimilação de ideias novas.

\section{Conclusão}

A disputa entre Júlio Ribeiro e Augusto Freire da Silva em torno da definição da gramática traz como questão a validade de princípios universais da palavra, debate que tem por base o embate entre universalidade e mutabilidade como princípios que governam a linguagem. Tomando partido da mutabilidade, Júlio Ribeiro evoca elementos como a evolução do cérebro e a ação do meio como fator da mudança linguística, meio esse descrito por itens como clima, alimentação e viver social, numa reflexão que rejeita a arbitrariedade e defende a lei da evolução. Augusto Freire da Silva, por seu turno, mesmo que não negue a mudança linguística, reconhecendo uma dimensão universal e uma dimensão particular do fenômeno linguístico, ambos regidos por princípios, não apenas sustenta a universalidade, como também rejeita qualquer influência do desenvolvimento cerebral na linguagem, numa defesa da imutabilidade dos princípios regentes da linguagem e numa teorização que traz como componentes o arbítrio dos povos e o gênio da língua.

Nesse confronto, como questões de ordem terminológica e mesmo epistemológica, está em discussão a interpretação acertada de autores, sendo exemplos centrais os nomes de Du Marsais e Teófilo Braga, e a pertinência de empregar ou não termos como princípio geral e o bom uso de outros termos 
como instituições, fatos e leis. Para Augusto Freire da Silva, a definição de gramática passa pela tomada em conta da composição do pensamento, numa aparente defesa de uma tradição filosófica frente aos avanços da gramática histórica. Para Júlio Ribeiro, a gramática se define numa rede de sentidos em que a linguagem é concebida por posições fortemente naturalistas, a partir do trabalho com a fisiologia e com o método histórico-comparativo. De qualquer forma, tanto Augusto Freire da Silva quanto Júlio Ribeiro tomam a gramática enquanto uma ciência, sendo variáveis justamente os critérios que sustentam um modo científico de fazer gramática.

A disputa entre uma divisão da gramática em quatro (prosódia, etimologia, sintaxe e ortografia) ou duas (lexeologia e sintaxe) partes, respectivamente as posições de Augusto Freire da Silva e de Júlio Ribeiro, organiza-se em volta da palavra e da tipificação dos seus elementos constitutivos e na na definição do que entra e do que fica fora da gramática, numa discussão que é também sobre o seu conteúdo e a sua utilidade. Ligado a tudo isso, há também um conflito a respeito da possibilidade de extensão de significação dos termos gramaticais, isto é, das condições que legitimariam ou não a mudança da significação original dos termos gramaticais, no que entra em jogo itens como tradição, benefícios, aceitação de outros gramáticos e de figuras de autoridade, no que se revela também uma contenda entre a gramática geral e a gramática histórica em termos de referências teóricas.

Em uma discussão sobre a (ir)racionalidade da classificação dos elementos gramaticais e que passa pela definição e a escolha de uma teoria filosófica e de uma lógica para o trabalho gramatical, com reflexões sobre as relações entre identidade de doutrina e terminologia, ambos os oponentes estão convencidos de seguir a verdadeira doutrina e de ter acompanhado o progresso a ciência, estando em combate justamente o que pode ser chamado de ciência e quem se colocaria legitimamente ao lado dela. O embate é sobre a verdadeira maneira científica de fazer gramática e de tratar a língua nacional, havendo concordância acerca do estatuto científico da gramática.

Para Júlio Ribeiro, a batalha seria entre o atraso representado pela metafísica e a modernidade trazida aos estudos gramaticais pela linguística, significada em relação à antropologia, à filologia e à gramática comparada, no rastro dos estudos fisiológicos sobre o desenvolvimento do cérebro e a teoria da evolução. Para Augusto Freire, contrariamente, a modernidade e cientificada da gramática seriam garantidas justamente por aquilo que seu oponente classifica negativamente como metafísica, isto é, toda uma tradição de reflexão sobre a linguagem a partir dos estudos da gramática geral. 
No apontamento de quem é preciso tomar como mestres, surge a reivindicação de um espaço de autoria, com o argumento de que não existe apenas repetição. Assim, tanto Júlio Ribeiro quanto Augusto Freire da Silva estabelecem uma diferença entre o gramático brasileiro e o gramático português, com julgamento favorável do primeiro em detrimento do segundo, num elogio da instauração do novo por parte do Brasil, argumento do novo esse que, em disputa, é ligado ao trabalho não apenas com a gramática histórica e comparada, mas também com a gramática geral.

A presença da gramática geral no Brasil na virada para o século XX pode ser trabalhada como uma contribuição brasileira para história das ideias linguísticas no cenário internacional na medida em que contradiz justamente a posição ainda muito em voga na história da linguística de que a gramática geral morre como paradigma com a instauração do método histórico e comparado. No Brasil do fim do século XIX, ela não apenas continua a animar a reflexão sobre a linguagem, como também é tomada como modelo de cientificidade, por autores como o maranhense Augusto Freire da Silva. Por outro lado, é preciso considerar também que a ligação de Júlio Ribeiro com a gramática histórica e comparada não se dá sem intervenções e interpretações particulares, demonstrando que ele apresenta uma leitura não ortodoxa de elementos centrais do comparativismo, tomando em conta fatores de ordem social, econômica, política e cultural como critérios para a mudança linguística. Assim, se há modelos concorrentes de cientificidade da gramática em disputa no Brasil no fim do século XIX, é preciso considerar também que eles não foram uma simples repetição da produção internacional, mas modos de conceber a linguagem e as línguas que foram ressignificados pelos gramáticos brasileiros.

É preciso registar por fim a existência de todo um movimento gramatical importante além do eixo Rio de Janeiro-São Paulo no Brasil na virada do século XIX para o XX, como mostra a produção realizada por autores do Maranhão, como Sotero dos Reis, defendida pelo igualmente maranhense Augusto Freire da Silva, o que nos permite afirmar, portanto, que as disputas entre a gramática geral e a gramática histórica e comparada no Brasil oitocentista não se reduziam apenas a uma rixa entre São Paulo e Rio de Janeiro, mas tinham uma amplitude nacional, além de atestar que a introdução da gramática nesses dois estados não significou o fim da produção de gramáticas em outras regiões do país. 


\section{Referências}

ALLEN, A.; CORNWELL, J. English Grammar. Londres: Simpkin, Marshall, \& Co., 1855.

AQUINO, José Edicarlos de. Júlio Ribeiro na história das ideias linguísticas no Brasil. 2016. 354 p. Tese - Instituto de Estudos da Linguagem, Universidade Estadual de Campinas, Campinas, 2016.

AYER, C. Grammaire comparée de la langue française. Bale: H. Georg, 1876. BASTIN, J. Étude Philologique de la Langue Française. São Petesburgo: Trenké \& Fusnot, 1878.

Bergman, F. G. Résumé d'études d'ontologie générale et de linguistique générale. Paris: Joël Cherbuliez, 1869.

BURGRAFF, P. Principes de Grammaire Générale. Liège: Imprimerie de H. Dessain, 1863.

Chapsal, Charles-Pierre; Noël, François. Nouvelle grammaire française avec exercices. Paris: Vve Nyon jeune, 1823.

Girault-Duvivier, CH-P. Grammaire des grammaire ou analyse raisonnée des meilleurs traités sur la langue française. Paris: Porthmann, 1812.

Müller, Max. La science du langage. Paris: Durand et Pedone-Lauriel, 1876. ORLANDI, Eni P. Língua e conhecimento linguístico: para uma história das ideias linguísticas no Brasil. São Paulo: Cortez, 2002.

. O Estado, a gramática, a autoria: língua e conhecimento linguístico. Línguas e Instrumentos Linguísticos. Campinas, n. 4/5, p. 19-34, 2000. ORLANDI, Eni P.; GUIMARÃES, Eduardo. Formação de um espaço de produção linguística: a gramática no Brasil. In: Orlandi, Eni P. (Org.) História das ideias linguísticas: construção do saber metalinguístico e constituição da língua nacional. Mato Grosso: Pontes, 2001. p. 21-38.

PFEIFFER, Claudia C. A língua nacional no espaço das polêmicas do século XIX/XX. In: Orlandi, Eni P. (Org.) História das ideias linguísticas: construção do saber metalinguístico e constituição da língua nacional. Mato Grosso: Pontes, 2001. p. 167-183.

Poitevin, M. P. Grammaire générale et historique de la langue française. Paris: Magasin Pittoresque, 1856.

RIBEIRO, Júlio. Questão grammatical. São Paulo: J. Lousada \& Comp., 1887. TOPINARD, Paul. L'Anthropologie. Paris : C. Reinwald et Cie. Libraires-Éditeurs, 1876. 
SILVA, Maurício. Júlio Ribeiro polemista: um capítulo da história das querelas linguísticas no Brasil. Polifonia. Cuiabá: v. 22, n. 1, p. 64-74, 2010.

Recebido em 3 de novembro de 2019.

Aceito em 2 de fevereiro de 2020. 